\title{
Influence of lactation stages and rain periods on subclinical mastitis in meat producing ewes
}

\author{
Influência dos estágios de lactação e ocorrência de chuvas sobre a mastite \\ subclínica em ovelhas com aptidão para produção de carne
}

\author{
Luiz Francisco Zafalon ${ }^{I^{*}}$ Guilherme Aparecido Fim Júnior ${ }^{\text {II }}$ \\ Carolina Orlando Vaso ${ }^{\text {III }}$ Nahryda Samara dos Santos Lopes ${ }^{\text {IV }}$ \\ Josir Laine Aparecida Veschi ${ }^{\mathrm{V}}$ Raul Costa Mascarenhas Santana ${ }^{\mathrm{I}}$
}

\section{ABSTRACT}

Mastitis negatively influences the survival and weight gain of ovines for meat production. The purpose of this study was to investigate, in sheep for meat production, the occurrence of subclinical mastitis in ewes at the end of lactation and beginning of the consecutive lactation and to assess the composition and cellular characteristics of milk as a function of different rainfall indices. Mammary halves (821) of Santa Ines (479) and Morada Nova (342) ewes were examined. Milk samples were collected in two different moments of lactation: at weaning and postpartum of the consecutive lactation. Sample collection periods were called "dry" or "rainy" according to the rainfall index in the month immediately before the month of collection. The occurrence of subclinical mastitis at weaning in the Santa Ines and Morada Nova ewes were 16.4 and $12.6 \%$ in the dry period, and 17.7 and $23.5 \%$ in the rainy period, respectively. In the consecutive lactation period, the occurrences were 26.7 and $27.7 \%$ in the dry period and 41.8 and $39.1 \%$ in the rainy period, for the Santa Ines and Morada Nova ewes, respectively. Postpartum stage was critical for the occurrence of subclinical mastitis, as compared to that at the end of the previous lactation. Occurrence of the disease negatively influenced the SCC in the milk at the beginning of lactation and changed its composition, mainly in the rainiest periods, probably due to a difficulty in maintaining hygiene in the environment where the animals remained.

Key words: milk composition, somatic cell count, rainfall indices, sheep.

\section{RESUMO}

A mastite influencia negativamente na sobrevivência e no ganho de peso em ovinos com aptidão para produção de carne. O objetivo do presente estudo foi investigar, em ovelhas para produção de carne, a ocorrência de mastite ovina subclínica, no final de lactação e no início da lactação consecutiva, bem como avaliar as características composicionais e celulares do leite em função de diferentes índices pluviométricos. Metades mamárias (821) das raças 'Santa Inês' (479) e 'Morada Nova' (342) foram analisadas. As amostras de leite foram colhidas em dois estágios diferentes de lactação: no desmame e após o parto da lactação consecutiva. Os períodos de colheita de amostras foram denominados "seco" ou "chuvoso", conforme o índice de chuva no mês imediatamente antes ao mês da colheita. A ocorrência de mastite subclínica na desmama nas raças 'Santa Inês' e 'Morada Nova' foi de 16,4 e 12,6\% no periodo seco, e 17,7 e 23,5\% no período chuvoso, respectivamente. Na lactação consecutiva, as ocorrências foram 26,7 e 27,7\% no período seco e 41,8 e 39,1\% no periodo chuvoso, nas ovelhas 'Santa Inês' e 'Morada Nova', respectivamente. O periodo pós-parto foi crítico para a ocorrência de mastite subclínica, comparado àquele no final da lactação anterior. A ocorrência da doença teve uma influência negativa na CCS do leite no início da lactação e alterou sua composição, principalmente nos periodos mais chuvosos, provavelmente por dificuldade em manter a higiene no ambiente onde os animais permaneceram.

Palavras-chave: composição do leite, contagem de células somáticas, índices pluviométricos, ovinos.

\section{INTRODUCTION}

The subclinical mastitis interferes with the performance of ewes due to a reduction in their

\footnotetext{
IEmbrapa Pecuária Sudeste, Rod. Washington Luís, Km 234, CP 339, 13560-970, São Carlos, SP, Brasil. E-mail: luiz.zafalon@embrapa.br. ${ }^{*}$ Corresponding author.

IIPrograma de Pós-graduação em Medicina Veterinária Preventiva, Faculdade de Ciências Agrárias e Veterinárias (FCAV), Universidade Estadual Paulista (UNESP), Jaboticabal, SP, Brasil.

IIIDepartamento de Biomedicina, Centro Universitário Central Paulista (UNICEP), São Carlos, SP, Brasil.

IV Programa de Pós-graduação em Biotecnologia, Universidade Federal de São Carlos (UFSCAR), São Carlos, SP, Brasil.

vEmbrapa Semiárido, Petrolina, PE, Brasil.
} 
serum immunoglobulin level and milk production. Consequently, there is an increase in the mortality of lambs and a premature disposal of animals when the subclinical form of the disease evolves to the clinic one, thus limiting economic exploitation in meat-producing sheep (COUTINHO et al., 2006; MAROGNA et al., 2010). PEREIRA et al. (2014) reported a reduction in weight gain of suckling lambs in farms with mastitis cases and neonatal lamb deaths due to absence or decrease in milk production by ewes.

Lactation stage and natural resistance of the mammary gland, among other factors, determine occurrence of the disease (CLEMENTS et al., 2003; VAUTOR et al., 2005, PEIXOTO et al. 2010). Climate of the place where sheep are raised has a relationship with an increased prevalence of mastitis, when they are raised in intensive conditions (CAROPRESE, 2008). According to some reports, mastitis occurs at different times of the year. However, some studies indicated a higher occurrence of mastitis during the rainy periods, probably because of a difficulty in cleaning and sanitizing the facilities and an increase in the concentration of environmental microorganisms (PEIXOTO et al. 2010; GARNICA et al., 2013). High temperatures also seem to negatively impact the quality of sheep milk. In a study conducted in Italy, SEVI et al. (2004) advocated management strategies during summer to reduce temperature effects on lactating ewes.

In the early stage of lactation, there is a higher incidence of mastitis due to peak in milk production. Differently, the weaning stage is associated with lower rates of the disease, except when the producer uses management practices such as early weaning. This condition may favor the development of infection in ewes with higher milk production by retaining the milk in the glands (PEREIRA et al., 2014). There are studies about the influence of climate or stage of lactation on disease occurrence in ewes with lower dairy potential, as well as with the cellular characteristics of these sheep (BLAGITZ et al., 2008; BLAGITZ et al., 2012; BLAGITZ et al., 2013). However, additional information will be useful in an attempt to relate these factors to changes in the composition of milk from these animals.

Thus, the purpose of this study was to investigate the occurrence of subclinical mastitis at the end of lactation and beginning of the consecutive lactation in ewes for meat-producing ewes, as a function of different rainfall indices, as well as to assess the composition and cellular characteristics of milk.

\section{MATERIALS AND METHODS}

\section{Characteristics of the flock}

The flock was within a farm in the municipality of São Carlos, SP, Brazil, where milk samples were obtained in the period between June 2012 and May 2014. Mammary halves (821) of Santa Ines (479) and Morada Nova (342) ewes were examined. All animals were submitted to the same system of semiintensive management, kept in paddocks with Coast-cross and Brachiaria decumbens grass and supplemented with daily supply of corn silage, mineral salt, and water ad libitum.

Animals were between the first and fourth lambing seasons and had one or two offspring. They were uniformly distributed in the groups studied, according to the lactation stage and rainy season. In the morning or afternoon prior to the day of sampling, lambs were separated from the ewes to allow obtaining milk in an amount sufficient for analysis.

\section{Milk sampling}

Milk samples were collected in two lactation stages: up to three days before drying off the ewes, i.e, at weaning; and 10-14 days after birth (postpartum stage) in the consecutive lactation. At weaning, udder halves (538) of Santa Ines (325) and Morada Nova (213) ewes were used. Other halves (283) of the Santa Ines (154) and Morada Nova (129) breeds were evaluated in the postpartum stage. All sheep evaluated in the postpartum stage were also evaluated at weaning. However, not all of them were available for study in the postpartum stage.

The California Mastitis Test (CMT) from the initial fractions of milk was performed for a preliminary identification of subclinical cases of mastitis. All degrees of reaction were considered positive and the samples were collected regardless of the results obtained in the test (NUNES et al., 2008). Immediately after the CMT, the samples were aseptically collected from each mammary gland for microbiological confirmation of subclinical mastitis.

Antisepsis of the teats using 70\% isopropyl alcohol was performed, and two samples containing approximately $5 \mathrm{~mL}$ of milk were collected from each mammary half. These samples were placed in sterile glass tubes and were subjected to microbiological tests. These samples were immediately sent to the Laboratory of Microbiology, on the farm, for microbiological identification, or frozen and stored to continue the procedures thereafter, according to laboratory availability. 
Microbiological analysis and intramammary infection definition

A microbiological diagnosis of subclinical mastitis was made after observing bacterial growth on the surface of Petri dishes containing $5 \%$ ovine blood agar plates and MacConkey agar. The plates were incubated under aerobic conditions for up to 72 hours at $37^{\circ} \mathrm{C}$, with readings at intervals of 24 hours, after plating of $0.01 \mathrm{~mL}$ of milk from an individual gland. The macroscopic characteristics of the colonies were evaluated, such as morphology, pigment production and hemolysis. Microorganism identification was performed in accordance with morphological, staining and biochemical characteristics. When three or more colony types were isolated from a sample, contamination was assumed. Samples were obtained by duplicate. A case of mastitis was defined when one or more colonies equal (the same morphology and size, pigmentation and type of hemolysis), until two different types were identified in the two samples (HARMON et al., 1990), in association with somatic cell count (SCC) higher than $250 \times 10^{3}$ cells $\mathrm{mL}^{-1}$. Other cases in disagreement with this condition were considered negative for mastitis. Results of the microbiological tests were interpreted according to BRITO et al. (1999).

Somatic cell count and milk composition

Milk samples for SCC and analysis of the fat, protein, and lactose levels, total solids (TS), and non-fat solids (NFS) were collected in plastic bottles (capacity: 60mL; with bronopol) immediately after collection for microbiological examination. The somatic cells were counted by flow cytometry, using the Somacount 300 (Bentley Instruments, Chaska, USA) electronic counter, whereas the milk composition was determined by the infrared absorption method, using the Bentley 200 (Bentley Instruments, Chaska, USA) equipment. Samples were sent for analysis in a laboratory accredited by the Brazilian Network for Milk Quality (Rede Brasileira de Qualidade do Leite; Piracicaba, SP, Brazil), where the equipment were calibrated for analysis of bovine milk.

Classification of lactation periods as a function of the rainfall indices

The sample collection periods were called "dry" or "rainy" according to the rainfall indices recorded in the month immediately before the collection. The overall rain averages were calculated for the rainy $(182.6 \mathrm{~mm})$ and dry $(48.4 \mathrm{~mm})$ periods. In the postpartum stage, the overall rainfall averages were also calculated for the rainy $(236.0 \mathrm{~mm})$ and dry $(67.0 \mathrm{~mm})$ periods. To obtain the rainfall indices, a meteorological station was installed in the study farm, near the place where the sheep remained. Classification of the sample collection periods followed historical rainfall averages for each month of the year in the region, except in June 2012, when the amount of rainfall exceeded the historical average.

\section{Statistical analyses}

Frequencies of subclinical mastitis were compared by using the Chi-square test. Significant values close to those of reference significance were adjusted according to the Yates continuity correction. The "odds ratio" (OR) was calculated when significance was observed to evaluate the lactation stage and rainfall indices as risks factor. In the confrontations with significance at the Chisquare test, all OR values calculated for the $95 \%$ confidence intervals were greater than 1.0. After descriptive analysis of the SCC, fat, protein, lactose, TS, and NFS variables, the data related to the milk composition and SCC were analyzed by means of the Tukey-Kramer test for multiple comparisons. Values obtained for the SCC were transformed into the logarithmic scale for analysis. Kolmogorov and Smirnov normality test was employed and the Bartlett test was used to confirm that the differences between the standard deviation values were not significant. The canonical correlation, a model of multivariate analysis, was performed to measure the associations among the variables. Values assigned to the variables breed, presence of mastitis, lactation stage and the rainfall indices were 1 to Santa Inês and 2 to Morada Nova breed; 1 and 2 to presence and absence of mastitis, respectively; 1 to weaning and 2 to postpartum; and 1 and 2 to dry period and rainy period, respectively. Differences with $P<0.05$ were considered significant (SAMPAIO, 1998). Statistical analyses were performed using the GraphPad Instat 3.0 (GraphPad Software, Inc., San Diego, California, USA) and BioEstat 5.3 (Software, Inc., University of Illinois, USA) programs.

\section{RESULTS AND DISCUSSION}

Occurrences of subclinical mastitis in the ewes are shown in table 1

When the two lactation periods (postpartum and weaning stages) were compared, the occurrence of subclinical mastitis in postpartum for the Santa Ines ewes in the rainy period was higher than in the weaning in both dry and rainy periods. However, 
Table 1 - Occurrence of subclinical mastitis in mammary halves of the Santa Ines and Morada Nova ewes at two different stages of lactation and in the rainy and dry periods.

\begin{tabular}{|c|c|c|c|c|c|c|c|}
\hline \multicolumn{2}{|c|}{----------Weaning stage----------- } & \multicolumn{2}{|c|}{----------Postpartum stage---------- } & \multicolumn{2}{|c|}{------Weaning stage---------- } & \multicolumn{2}{|c|}{---------Postpartum stage---------- } \\
\hline Dry period $^{1}$ & Rainy Period $^{2}$ & Dry period & Rainy period $^{1,2}$ & Dry Period $^{3,4}$ & Rainy Period $^{5}$ & Dry period $^{3}$ & Rainy period ${ }^{4,5}$ \\
\hline $33(16.4 \%)^{\mathrm{b}}$ & $22(17.7 \%)^{\mathrm{b}}$ & $20(26.7 \%)^{\mathrm{a}, \mathrm{b}}$ & $33(41.8 \%)^{\mathrm{a}}$ & $14(12.6 \%)^{\mathrm{c}}$ & $24(23.5 \%)^{\mathrm{b}, \mathrm{c}}$ & $18(27.7 \%)^{\mathrm{a}, \mathrm{b}}$ & $25(39.1 \%)^{\mathrm{a}}$ \\
\hline
\end{tabular}

Different letters between the Santa Ines ewes $P<0.05$; Different letters between the Morada Nova ewes $P<0.05$.

${ }^{1}$ Odds ratio $(\mathrm{OR})+95 \%$ confidence interval $(95 \% \mathrm{CI})=3.65$ (2.04 to 6.54).

${ }^{2} \mathrm{OR}+95 \% \mathrm{CI}=3.33$ (1.75 to 6.32$)$.

${ }^{3} \mathrm{OR}+95 \% \mathrm{CI}=2.65(1.22$ to 5.79$)$

${ }^{4} \mathrm{OR}+95 \% \mathrm{CI}=4.44$ (2.09 to 9.43$)$.

${ }^{5} \mathrm{OR}+95 \% \mathrm{CI}=2.08(1.06$ to 4.11$)$.

similar results were reported by PEREIRA et al. (2014), although these authors have analyzed clinical mastitis. According to these authors, the period with the highest occurrence of the disease was observed in the beginning of lactation. In the present study, the ewes had a long (90-120 days) lactation period. It is likely that the small amount of milk within the mammary gland before the weaning stage influenced the lower incidence of subclinical mastitis caused by micro-organisms, as compared to the occurrence in the postpartum stage. Early weaning was not used on the farm, because this type of management could cause an increase in disease prevalence.

Predominance of CNS among the microorganisms isolated in the cases of subclinical mastitis (Table 2) is in agreement with that reported by other authors (SPANU et al., 2011; FRAGKOU et al., 2014; PEREIRA et al., 2014). In table 3, the mean values for the milk characteristics of interest are shown according to the sheep breeds and the dry and rainy periods, in the weaning and postpartum stages of the consecutive lactation.
Santa Ines ewes showed the highest SCC in the rainy period of the postpartum stage. Higher SCC in the postpartum stage, as compared to those in the weaning stage, are in agreement with a higher incidence of subclinical mastitis in the consecutive lactation (Table 1). After lambing, the mammary halves of ewes showed physiological changes that can facilitate the entrance of micro-organisms in the mammary glands. For example, animals with high amounts of milk in the mammary gland present a less effective control against the entry of pathogens. In addition, the physical stress caused by frequent suckings by the offspring can cause micro-lesions in the teats of ewes.

In Brazil, an official critical limit for SCC in sheep milk does not exist. KERN et al. (2013) reported the value of 400,000 cells per $\mathrm{mL}$ of milk in breeds for meat production as being useful limit for producers to detect problems in the mammary glands. During the postpartum stage, the occurrence of subclinical mastitis was higher than in the weaning stage, and the SCCs were higher than 400,000 cells

Table 2 - Microorganisms isolated in the cases of ovine subclinical mastitis at two different stages of lactation and in the rainy and dry periods.

\begin{tabular}{|c|c|c|c|c|}
\hline \multirow{2}{*}{ Microorganisms } & \multicolumn{2}{|c|}{----------------Weaning stage-------------- } & \multicolumn{2}{|c|}{---------Postpartum stage---------- } \\
\hline & Dry period & Rainy period & Dry period & Rainy period \\
\hline Coagulase-negative Staphylococcus (CNS) & $57.4 \%$ & $51.1 \%$ & $60.5 \%$ & $63.8 \%$ \\
\hline Enterobacteria & $21.3 \%$ & $13.3 \%$ & $5.3 \%$ & $17.2 \%$ \\
\hline Streptococcus spp & $8.5 \%$ & $11.1 \%$ & $26.3 \%$ & $6.9 \%$ \\
\hline Corynebacterium spp & $4.3 \%$ & $6.7 \%$ & - & - \\
\hline Coagulase-positive Staphylococcus & - & $13.3 \%$ & - & $10.3 \%$ \\
\hline Association CNS plus Streptococcus spp & $4.3 \%$ & - & $2.6 \%$ & - \\
\hline Micrococcus spp & $4.3 \%$ & $4.4 \%$ & - & $1.7 \%$ \\
\hline Yeast & - & - & $5.3 \%$ & - \\
\hline
\end{tabular}


Table 3 - Mean values for characteristics of interest in milk from the Santa Ines and Morada Nova ewes in different lactation stages and rainfall periods.

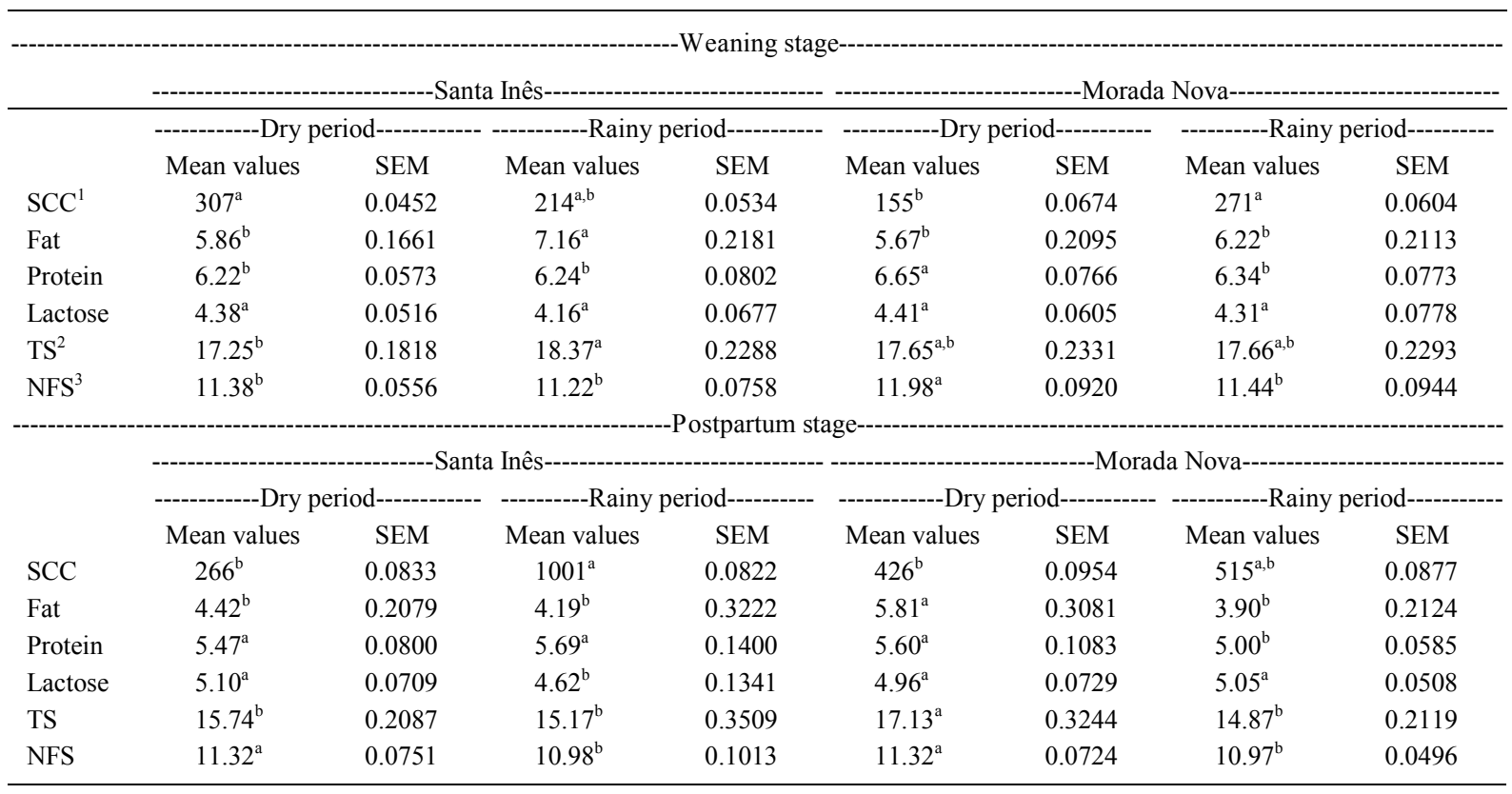

SEM: Standard error of the estimate; ${ }^{1}$ Somatic cell count $\left(\times 10^{3}\right.$ cells/mL of milk); ${ }^{2}$ Total solids; ${ }^{3}$ Non-fat solids; Fat, Protein, Lactose, TS, NFS: $\%$.

per $\mathrm{mL}$ of milk in the Morada Nova and Santa Ines ewes (the latter only in the rainy period).

Association of variables according to breed, subclinical mastitis, lactation stage and rainfall indices was carried out (Table 4). The increase of the SCC was significantly related to subclinical mastitis as well as the rainy periods. The rainfall indices also influenced negatively the protein, lactose and nonfat solids. In the postpartum stage of the following lactation, significant differences occurred to all variables. In the study farm, the animals were kept indoors at night to avoid predation by wild animals. The increase in population density at night, mainly in the rainiest periods of the warmest months, favored accumulation of organic matter. This may have exposed the sheep to the action of microorganisms and development of infection. Consequently, a rise was observed in the SCC, with changes in the other milk components. Levels of lactose and non-fat solids were also positively correlated to rainfall indices, while the fat, protein and total solids levels were negatively correlated to the rainfall indices.

Table 4 - Association between groups of variables (X and Y) represented by the characteristics of the milk of ewes with and without subclinical mastitis of different breed and two stages of lactation and two rainfall indices.

\begin{tabular}{llcc}
\hline \multirow{2}{*}{ Variables X } & & & \\
& Breed & Mastitis & Lactation Stage \\
\hline Somatic cell count & $-0,056$ & $-0,505^{*}$ & $0,213^{*}$ \\
Fat & $-0,033$ & $-0,031$ & $-0,313^{*}$ \\
Protein & 0,015 & $-0,056$ & $-0,436^{*}$ \\
Lactose & $0,104^{*}$ & $0,207^{*}$ & $0,312^{*}$ \\
Total Solids & 0,013 & 0,014 & $-0,349^{*}$ \\
Non-Fat Solids & $0,139^{*}$ & $0,135^{*}$ & $-0,092^{*}$ \\
\hline
\end{tabular}

${ }^{*} \mathrm{P}<0.05$. 
Changes in milk composition can be harmful to the weight gain in lambs, due to a reduction in the quality and production of milk in mammary glands with subclinical mastitis (SOUZA et al., 2005). Further studies on this subject should be conducted to help producers and technicians and generate new knowledge on the occurrence of subclinical mastitis in meat-producing ewes. New information about the disease can be used to elucidate issues related to the epidemiology of mastitis and facilitate future control action.

\section{CONCLUSION}

The postpartum stage was critical for the occurrence of subclinical mastitis, as compared to the end of the previous lactation. The occurrence of mastitis negatively influenced milk SCC in this period and led to changes in milk composition, mainly in the rainiest periods by difficulty in maintaining hygiene in the environment where the animals were kept.

\section{ACKNOWLEDGEMENTS}

Fundação de Amparo à Pesquisa do Estado de São Paulo (FAPESP) (Grant number 2012/03847-1).

\section{REFERENCES}

BLAGITZ, M.G. et al. Cellular and microbiological profile of Santa Ines ewes in the lactation and the post-weaning period. Pesquisa Veterinária Brasileira, v.28, n.9, p.417-422, 2008. Available from: <http://www.scielo.br/scielo.php?pid=S0100736X2008000900004\&script=sci_arttext $>$. Accessed: Sept. 04, 2015. doi: 10.1590/S0100-736X2008000900004.

BLAGITZ, M.G. et al. Lactation stage and udder health status of Santa Ines ewes. Arquivo Brasileiro de Medicina Veterinária e Zootecnia, v.64, n.2, p.495-498, 2012. Available from: $\quad<$ http://www.scielo.br/readcube/epdf. php?doi=10.1590/S010209352012000200034\&pid=S0102$09352012000200034 \&$ pdf_path=abmvz/v64n2/a34v64n2. pdf\&lang=en $>$. Accessed: Sept. 04, 2015.

BLAGITZ, M.G. et al. Effect of lactation stage on milk physicochemical characteristics and somatic cell count from Santa Ines ewes. Ciência Animal Brasileira, v.14, n.4, p.454-461, 2013. Available from: <http://www.revistas.ufg.br/index.php/ vet/article/view/14028/15633>. Accessed: May 21, 2015. doi: 10.5216/cab.v14i4.14028>.

BRITO, M.A.V.P. et al. Dairy herds pattern of intramammary infection: evaluation of all mammary quarters of lactating cows. Arquivo Brasileiro de Medicina Veterinária e Zootecnia, v.51, n.2, p.129-135, 1999. Available from: <http://www.scielo. br/scielo.php?script $=$ sci_arttext\&pid $=$ S0102093519990002000 01\&lng=en\&nrm=iso\&tlng=pt $>$. Accessed: Dec. 03, 2015. doi: 10.1590/S0102-09351999000200001.
CAROPRESE, M. Sheep housing and welfare. Small Ruminant Research, v.76, n.1-2, p.21-25, 2008. Available from: <http:// www.sciencedirect.com/science/article/pii/S0921448807002878>. Accessed: Sept. 02, 2015. doi: 10.1016/j.smallrumres.2007.12.015.

CLEMENTS, A.C.A. et al. Evaluation of diagnostic procedures for subclinical mastitis in meat-producing sheep. Journal of Dairy Research, v.70, n.2, p.139-148, 2003. Available from: <http://journals.cambridge.org/download. php? file=\%2FDAR\%2FDAR70_02\%2FS0022029903006022a. pdf\&code $=1524 \mathrm{e} 130371$ eabeca52396b9fb4b0cce $>$. Accessed: Apr. 15, 2015. doi: 10.1017/S0022029903006022.

COUTINHO, D.A. et al. Aetiology and in vitro antimicrobial susceptibility of isolated bacterias from Santa Inês ewes with subclinical mastitis. Revista Brasileira de Saúde e Produção Animal, v.7, n.2, p.139-151, 2006. Available from: <http:// revistas.ufba.br/index.php/rbspa/article/view/712/457>. Accessed: May 19, 2015.

FRAGKOU, I.A. et al. Diagnosis of clinical or subclinical mastitis in ewes. Small Ruminant Research, v.118, p.86-92, 2014. Available from: <http://www.sciencedirect.com/science/ article/pii/S0921448813004264>. Accessed: Jun. 17, 2015. doi: 10.1016/j.smallrumres.2013.12.015.

GARNICA, M.L. et al.Staphylococcus aureus and Escherichia coli prevalence in ovine bulk tank Milk. Small Ruminant Research, v.115, p.108-112, 2013. Available from: $<$ http://www.sciencedirect. com/science/article/pii/S0921448813002885?np=y>. Accessed: Sept. 03, 2015. doi: 10.1016/j.smallrumres.2013.09.001.

HARMON, R.J. et al. Microbiological procedures for the diagnosis of bovine udder infections. Arlington: National Mastitis Council; 1990. 34p.

KERN, G. et al. Analysis of somatic cell counts and risk factors associated with occurrence of bacteria in ewes of different primary purposes. Livestock Science, v.157, p.597-604, 2013. Available from: <http://www.sciencedirect.com/science/article/ pii/S1871141313004034>. Accessed: Jun. 09, 2015. doi: 10.1016/j.livsci.2013.09.008.

MAROGNA, G et al. Clinical findings in sheep farms affected by recurrent bacterial mastitis. Small Ruminant Research, v.88, p.119-125, 2010. Available from: <http://www.sciencedirect.com/ science/article/pii/S0921448809002910>. Accessed: Sept. 02, 2015. doi: 10.1016/j.smallrumres.2009.12.019.

NUNES, G.R. et al. Evaluation of the indicators of inflammation in the diagnosis of ovine mastitis. Arquivos do Instituto Biológico, v.75, p.271-278, 2008. Available from: <http://www.biologico. sp.gov.br/docs/arq/v75_3/nunes.pdf>. Accessed: Dec. 02, 2015.

PEIXOTO, R.M. et al. Small ruminant mastitis in Brazil. Pesquisa Veterinária Brasileira, v.30, n.9, p.754-762, 2010. Available from: $<$ http://www.scielo.br/scielo.php?script $=$ sci_ arttext\&pid=S0100736X200000900008\&lng=en\&nrm=iso\&tlng= pt>. Accessed: Apr. 09, 2015. doi: 10.1590/S0100736X2010000900008.

PEREIRA, P.F.V. et al. Risk factors, etiology and clinical aspects of mastitis in meat ewes of Parana, Brazil.. Pesquisa Veterinária Brasileira, v.34, n.1, p.1-10, 2014. Available from: <http://www. scielo.br/pdf/pvb/v34n1/01.pdf>. Accessed: May 21, 2015. doi: 10.1590/S0100-736X2014000100001. 
SAMPAIO, I.B.M. Estatística aplicada à experimentação animal. Belo Horizonte: Fundação de Ensino e Pesquisa em Medicina Veterinária e Zootecnia. 1998. 221p.

SEVI, A. et al. Effects of lambing season and stage of lactation on ewe milk quality. Small Ruminant Research, v.51, n.3, p.251-259, 2004. Available from: <http:/www.sciencedirect.com/ science/article/pii/S0921448803001962>. Accessed: Sept. 02, 2015. doi: 10.1016/S0921-4488(03)00196-2.

SOUZA, A.C.K.O. et al. Production, chemical composition and physical characteristics of sheep milk in Corriedale breed. Revista Brasileira de Agrociência, v.11, n.1, p.73-77, 2005. Available from: <http://www2.ufpel.edu.br/faem/agrociencia/v11n1/ artigo 12.pdf $>$. Accessed: Jun. 02, 2015.
SPANU, C. et al. Impact of intramammary antimicrobial dry treatment and teat sanitation on somatic cell count and intramammary infection in dairy ewes. Small Ruminant Research, v.97, p.139-145, 2011. Available from: $<$ http://www.sciencedirect.com/science/article/pii/ S0921448811000800>. Accessed: Jun. 17, 2015. doi: 10.1016/j. smallrumres.2011.03.005.

VAUTOR, E. et al. Characterization of 26 isolates of Staphylococcus aureus, predominantly from dairy sheep, using four different techniques of molecular epidemiology. Journal of Veterinary Diagnostic Investigation, v.17, p.363-368, 2005. Available from: <http://vdi.sagepub.com/ content/17/4/363.full.pdf + html $>$. Accessed: June 09, 2015. doi: $10.1177 / 104063870501700411$. 